\title{
EXTREME VARIABILITIES OF RAINFALL AND RUNOFF REGIME WITHIN VULNERABLE HYDROGRAPHIC RIVER BASINS. CASE STUDY: ELAN RIVER BASIN, 2016 (ROMANIA)
}

\author{
Andreea-Violeta Tudorache $e^{1,2}$
}

Key words: rainfall, maximum flow, defence levels, flash flood, damage

\begin{abstract}
Anstract.The present paper analyzes the extreme variabilities of rainfall and runoff regime within vulnerable hydrographic river basins, focused on a case study: Elan river basin, year 2016. This year, due to excess rainfall, the Elan River basin was affected by torrential rainfall, warned against by orange and red code hydrological forecasts. For this reason, this study makes an analysis of the spatial and temporal variability of the surface runoff also considering the main flood events occurring in this river basin. The impact of liquid precipitation on the surface runoff will be highlighted by a statistical analysis of the relationship between monthly average flows and the sum of monthly precipitation in the river basin. The monthly flows series from the Murgeni and Poșta Elan hydrometric stations were capitalized through appropriate statistical analyses. Maximum flows were reported to the thresholds values corresponding to the Defense Levels.
\end{abstract}

\section{Introduction}

The topic of water flow in general and flash floods in particular has been extensively debated in studies both at national level (Bîrsan et al., 2013; Diaconu, 1988; Petru et al.,1989; Pișota et al,. 2005; Stănescu et al., 2002; Ujvari, 1972) and also at international level (Dettinger, 2000; Milly et al., 2005).

An important characteristic of the rivers in Romania is the appearance, throughout the year, of high waters and floods resulting from heavy rainfall, snow melting or overlapping of the two phenomena. The intensity and duration of floods is influenced by the existing physical-geographic conditions, climate elements (atmospheric precipitation) as well as relief factors being among the most important. In the future, the same trend is also foreseen to maintain, its main cause being the global climate change.

\footnotetext{
${ }^{1}$ Faculty of Geography, University of Bucharest, Romania

${ }^{2}$ National Institute of Hydrology and Water Management, e-mail: tudoracheav@gmail.com
} 
In 2016, due to excessive rainfall, the Elan River basin was affected by torrential rainfall, which led to issuing of orange and red code hydrological warnings. This study makes an analysis of the spatial and temporal variability of the surface runoff, also considering the main flood events recorded in this river basin. The purpose of this paper is to highlight the way in which the surface runoff varied in 2016 in the Elan River basin, in relation to the pluviometric regime, the dangerous hydro-meteorological phenomena that have taken place, but also to their impact on society and on the environment.

\section{Study area}

The Elan River is a tributary of the Prut River, which overlaps almost entirely over the Vaslui County. The catchment area of the river occupies an area of approximately $606 \mathrm{~km}^{2}$, the length of the river being $73 \mathrm{~km}$. Some of the localities that it flows across are: Urlaţi, Hurdugi, Gușiţei, Poşta Elan, Murgeni, located south of Huși town (Fig. 1).

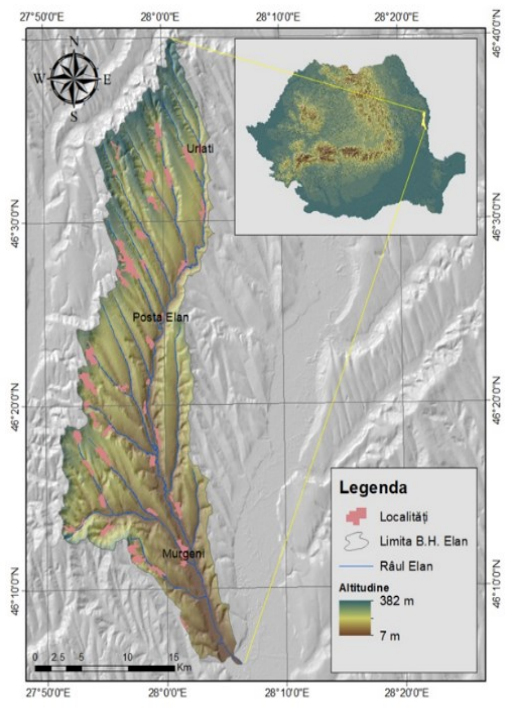

Fig. 1 - Location of the study area

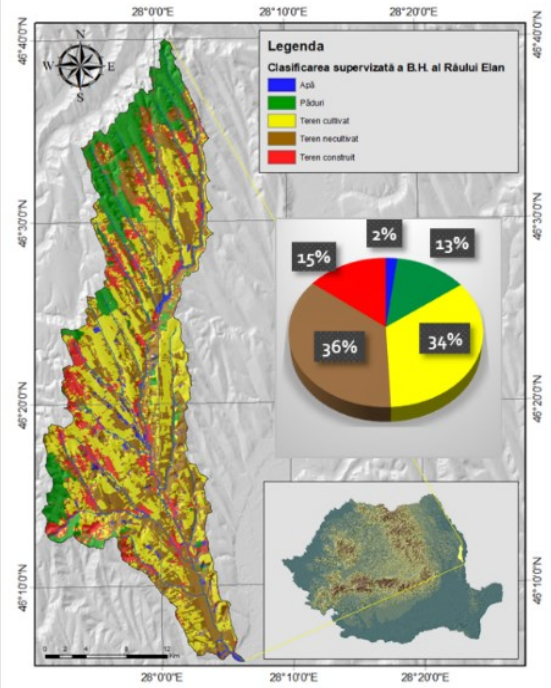

Fig. 2 - Land cover/ use (supervised classification) in the Elan River basin, processing in the ArcMap software package

After the application of the supervised pixel classification process, there resulted a number of 5 classes of land cover/use. For the studied area, uncultivated areas have the highest percentage, which occupies over $36 \%$ of the total of over 
$600 \mathrm{~km}^{2}$ of the area under research. This class is followed by cultivated areas accounting for about $34 \%$ of the study area. The lowest percentage is held by bodies of water, their surface area accounting for approximately $2 \%$ of the total areaof the Elan river basin (Fig.2).

\section{Data\& methods}

To be able to make an assessment of the impact of liquid precipitation on the surface runoff, a statistical analysis was made regarding the relationship between maximum monthlyflows and the sum of monthly precipitation in the river basin. The maximum monthly flows series from the Murgeni and Poșta Elan hydrometric stations were capitalized through appropriate statistical analyses. Maximum flows were reported to the threshold values corresponding to the Defense Levels. The current limnimetric key (Table no. 1) was used to determine the flow rate corresponding to the ATTENTION and FLOOD LEVELS.

In order to highlight the variability of the hydro-meteorological regime of the Elan River, by using the GIS software, a map of land use can be made based on satellite images and automatic pixel classification (Fig. 2). Land cover / land use can help determine some susceptibility indices in GIS, such as the Flash-Flood Potential Index and the Flood Potential Index, because different land cover / land use classes among other factors (slope, profile curvature, convergence index, etc.) has a different influence on surface water runoff.

In order to make a linear correlation, two data strings were used regarding the monthly precipitation sums and the maximum monthly flows of the Elan River at Murgeni hydrometric stations, year 2016. (Fig. 4). Maps were made by using a GIS software and the flood characteristics were calculated in the Cavis program.

Table no. 1 DEFENSE LEVELS and corresponding flows for selected hydrometric stations

\begin{tabular}{|c|c|c|c|c|c|c|c|}
\hline River & H.S. & $\mathbf{F}\left(\mathrm{km}^{2}\right)$ & H med $(\mathbf{m})$ & C.A. $(\mathbf{c m})$ & Q.A. $\left(\mathrm{m}^{3} / \mathbf{s}\right)$ & C.I. $(\mathbf{c m})$ & Q.I. $\left(\mathrm{m}^{3} / \mathbf{s}\right)$ \\
\hline \multirow{2}{*}{ Elan } & Murgeni & 410 & 168 & 350 & 10.8 & 450 & 60.5 \\
\cline { 2 - 8 } & Poșta Elan & 237 & 197 & 200 & 4.5 & 240 & 12.7 \\
\hline
\end{tabular}

H.S. = hydrometric station; $\mathrm{F}=$ river basin area; Hmed= river basin mean altitude; C.A./C.I.= attention/flood level; Q.A./Q.I.= attention/flood flow

(Data source: INHGA)

\section{Results}

Due to the significant amount of precipitations that occurred in short intervals of time and due to the significant runoff from the slopes, there were considerable increases in flow rates on the Elan river basins during the analyzed period (Fig. 5, 6). The highest recorded flow $\left(3.85 \mathrm{~m}^{3} / \mathrm{s}\right)$ was the one at Murgeni hydrometric station 
(14.10.2016), with a level of $330 \mathrm{~cm}$. At the analyzed hydrometric stations, the largest amounts of precipitations were recorded in the months in which flood events occurred, June and October (Fig. 3). The annual rainfall for the entire 2016 year-period was 584 $\mathrm{mm}$ at H.S. Murgeni and $494 \mathrm{~mm}$ at H.S. Poşta Elan. The characteristic elements of the flood waves are shown in Fig. 7, 8.

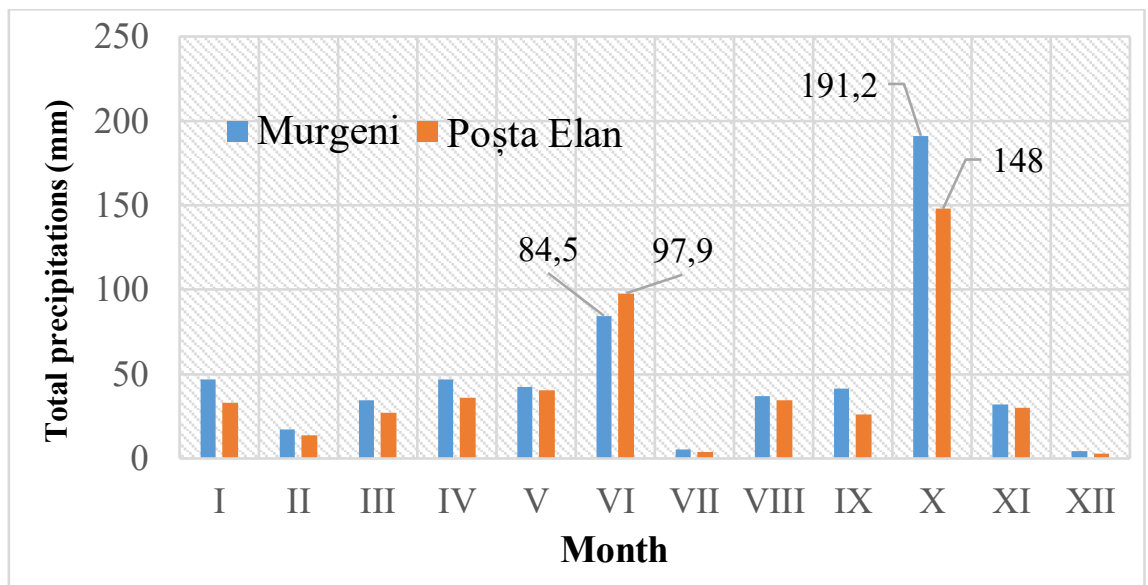

(Data source: INHGA)

Fig. 3. The sum of monthly precipitation at the analyzed hydrometric stations

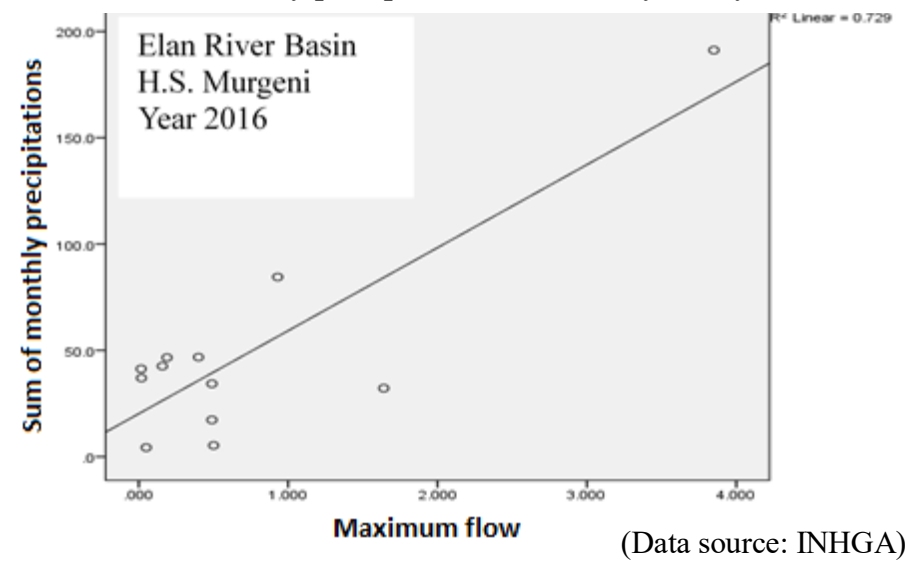

Fig. 4 - The correlation graph between the annual rainfall sum and the annual maximum flow rates

Following the application of a linear correlation between the two quantitative variables, the resulting Pearson correlation coefficient (r) was equal to 0.729 (Fig. 4). It shows that there is a relatively strong correlation between the two data series 
and at the same time statistically significant. It should also be noted that the two variables correlate positively, as Fig. 4 shows.

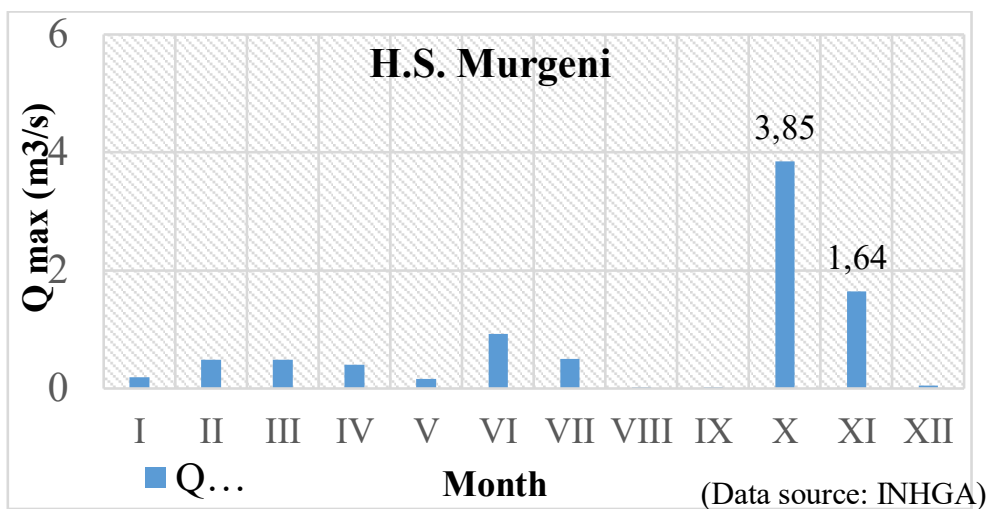

Fig. 5. Maximum annual flows at the Murgeni hydrometric station

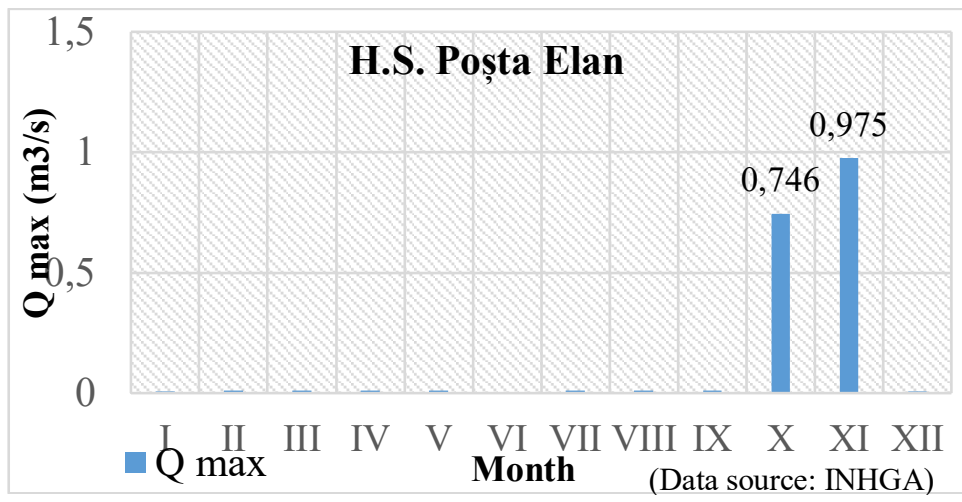

Fig. 6. Maximum annual flows at the Poșta Elan hydrometric station 


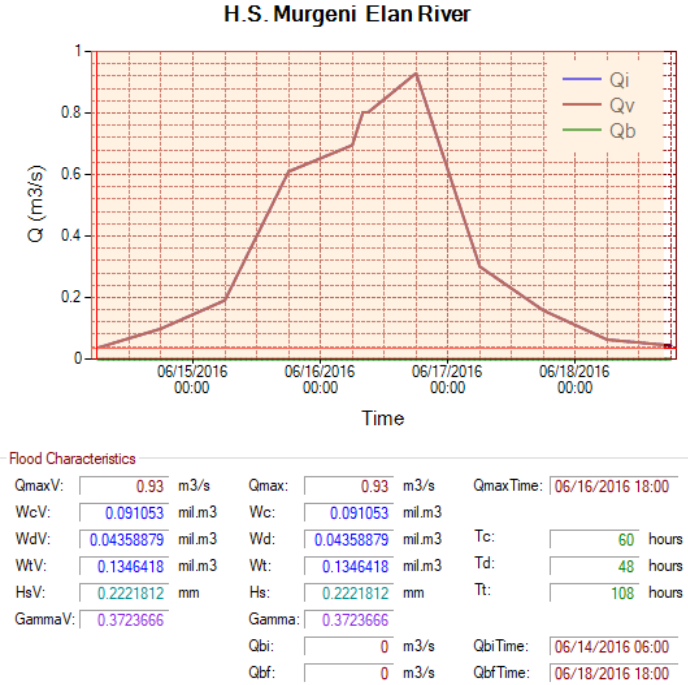

Fig.7. Characteristic elements of flood waves, June and October events, year 2016

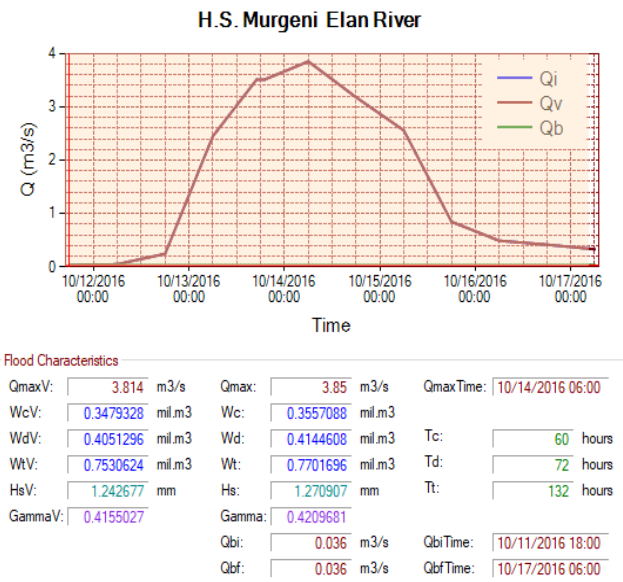

Fig.8 - Characteristic elements of flood waves, June and October events, year 2016

The atmospheric instability between 14-18.06.2016 and 11-17.10.2016, led to the recording of a considerable amount of precipitation in a short time, which caused significant runoff on the slopes, creating conditions for the formation of the flood waves in the Elan River basin. For this reason, the National Center for Hydrological Forecasting issued 4 yellow code and 3 orange code warnings (valid for the period 18-19.06.2016 and 12-13.10.2016) (Fig.9,10). 
The important amount of precipitations and the concentration of runoff on the slopes have caused floods and damage of some houses and household annexes, bridges, roads and arable lands, pastures and fountains.

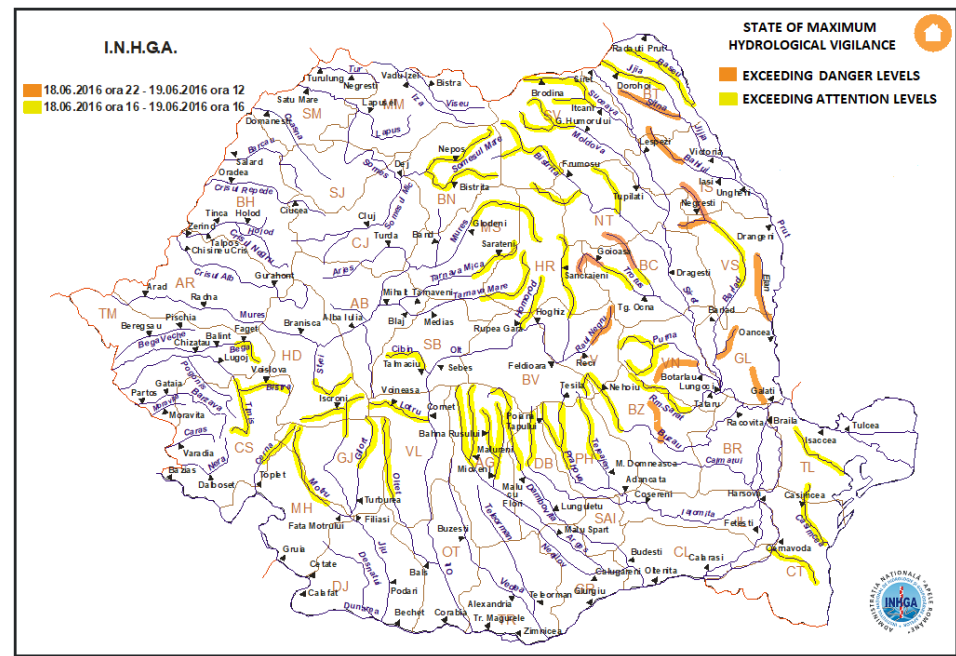

Fig. 9 - Hydrological warning map issued in 18-19 June 2016

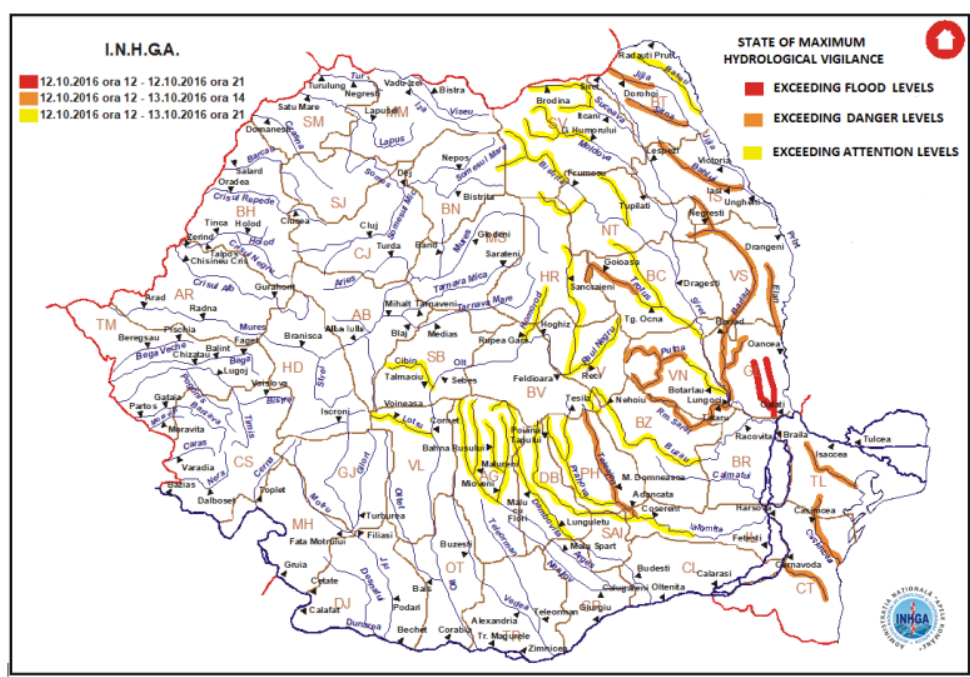

Fig. 10 - Hydrological warning map issued in 12-13 October 2016 
Regarding the evolution of the annual maximum flows, they are generally low, with a slight increase during the summer season, while in October and November, they reach the highest values. After applying the linear correlation, the result is relatively strong between the two parameters analyzed $(\sim 73 \%)$.

Regarding the dangerous hydro-meteorological phenomena, a flood produced in October can be noticed, when, at H.S. Murgeni, a maximum flow rate of 3.85 $\mathrm{m}^{3} / \mathrm{s}$ was recorded.

Following the floods, frequent damage occurs to houses, bridges, roads, arable land, pastures and fountains in affected areas.

The next step is to analyze the potential impacts of climate change on the hydrological regime of the maximum runoff in the Elan river basin.

\section{References}

Bîrsan M.V., Zaharia L., Chendeș V., Brănescu E. (2013) Seasonal trends în Romanian streamflow, Hydrol. Process, doi: 10.1002/hyp.9961

Dettinger, Michael D., et al. (2000) Multiscale streamflow variability associated with El Nino/Southern oscillation. Cambridge University Press

Diaconu C. (1988), Râurile de la inundaţii la secetă, Editura Tehnică, Bucureşti

Milly, Paul CD, Kathryn A. Dunne, Aldo V. Vecchia (2005) Global pattern of trends în streamflow and water availability in a changing climate. Nature, 438,7066:347-350.

Petru S., Stănescu Al. V., Roman P. (1989), Hidrologie Dinamică, Editura Tehnică, Bucureşti, 25-43.

Pișota, I., Zaharia, L., Diaconu, D. (2005), Hidrologie, Ed. Univeristară, București, 2041.

Stănescu Al. V., Dobrot R. (2002), Măsuri nestructurale de gestiune a inundaţiilor, Editura HGA, Bucureşti, 34-78.

Ujvari I. (1972), Geografia apelor României, Editura Științifică, București

WMO (2011), Manual on flood forecasting and warning

*** (1971) - Râurile României. Monografie hidrologică, IMH, București

*** (1992) - Atlasul Cadastrului apelor din România 1, partea I - date morfo-hidrologice asupra rețelei hidrografice de suprafață, Ministerul Mediului Aqaproiect S.A, București

*** Studii la staţiile hidrometrice. Arhiva INHGA 